\title{
Heat-balance Thermal Protection with Heat Pipes for Hypersonic Vehicle
}

\author{
Rong Yisheng ${ }^{1,2, a}$, Wei Yuechuan ${ }^{1,2}$, Duan Dongli ${ }^{1}$ and Zhan Renjun ${ }^{1}$ \\ ${ }^{1}$ Engineering University of the Armed Police Force, Xi'an 710086, PR China \\ ${ }^{2}$ National University of Defense Technology, Changsha 410073, PR China
}

Keywords: Heating Heat-balance Thermal Protection, Heat-pipe, Hypersonic, Aerodynamic Heating

\begin{abstract}
Heat-balance thermal protection is non-ablating thermal protection for leading edge of hypersonic vehicle. Heat will be quickly transferred from high aerodynamic heating area to low aerodynamic heating area, where the energy will be released by radiation. The temperature of high aerodynamic heating area could be reduced to protect the designed structure from being burned down. Heat-balance thermal protection is summarized. The research on heat-pipe for heat-balance thermal protection is introduced.
\end{abstract}

\section{Introduction}

There is serious aerodynamic heating during hypersonic flight. The heat flux on leading nose whose radius is $20 \mathrm{~mm}$ can reach $2 \sim 3 \mathrm{MW} / \mathrm{m} 2$ and the wall temperature can reach $1400 \mathrm{~K}$ when the vehicle Mach number is 7 and flight altitude is $24 \mathrm{~km}$. When traditional ablating thermal protection is used, the ablating material is burned out. During the ablation, aerodynamic heating is absorbed and released. However, the designed aerodynamic shape may be burned down, especially the sharp leading edge. The vehicle will be unable to fly in high Mach number if its structure is seriously ablated.

Heat-balance thermal protection is different from traditional thermal protection. Heat will be quickly transferred from high aerodynamic heating area to low aerodynamic heating area, where the energy will be released by radiation. The temperature of high aerodynamic heating area could be reduced to protect the designed structure from being burned down. It is nonablating thermal protection.

\section{Heat-balance thermal protections}

According to thermal protection mechanism, heat-balance thermal protection can be divided into single heat-balance thermal protection and combinational heat-balance thermal protection. In practice, single heat-balance thermal protection is hardly used. There are usually more two methods used together to achieve better thermal protect effect, which is shown in Table 1.

As widely used methods, the research on heat-pipe for heat-balance thermal protection is introduced.

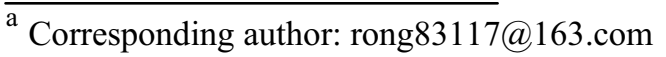


Table 1. Different heat-balance thermal protections

\begin{tabular}{|c|c|c|c|}
\hline Type & $\begin{array}{l}\text { Thermal Protect } \\
\text { Way }\end{array}$ & Materials & Thermal Protect Mechanism \\
\hline \multirow[t]{2}{*}{ Single } & $\begin{array}{l}\text { Using high thermal } \\
\text { conductivity } \\
\text { material }\end{array}$ & $\begin{array}{c}\text { Metal, high thermal } \\
\text { conductivity carbon material }\end{array}$ & Heat is conducted quickly with high thermal conductivity. \\
\hline & Using fluid & $\begin{array}{l}\text { Air, water, liquid } \mathrm{Na} \text {, liquid } \\
\mathrm{Li}\end{array}$ & Heat is conducted with fluid flowing \\
\hline \multirow[t]{4}{*}{ Combinational } & Nano-fluid & $\begin{array}{c}\text { Nano-sized particles with } \\
\text { fluid }\end{array}$ & $\begin{array}{l}\text { Heat is better conducted with fluid flowing and high thermal } \\
\text { conductivity of Nano-sized particles. }\end{array}$ \\
\hline & $\begin{array}{l}\text { Phase-changeable } \\
\text { material in special } \\
\quad \text { matrix }\end{array}$ & $\begin{array}{l}\text { Matrix is made of high } \\
\text { thermal conductivity material } \\
\text { filled with phase-changeable } \\
\text { material. }\end{array}$ & $\begin{array}{l}\text { Phase-changeable material will absorb heat while phase is } \\
\text { changing. After phase change, material becomes fluid. } \\
\text { Matrix made of high thermal conductivity for heat transfer } \\
\text { will also keep phase-changeable material from leaking out. }\end{array}$ \\
\hline & Heat-pipe & $\begin{array}{l}\text { Container is made of high } \\
\text { heat capacity material and } \\
\text { filled with full wetting } \\
\text { working fluid. }\end{array}$ & $\begin{array}{c}\text { Working fluid evaporates in evaporator first. Vapor will be } \\
\text { transported to condenser, where vapor condenses. Then } \\
\text { condensate will return to evaporator through a wick of } \\
\text { suitable capillary structure. }\end{array}$ \\
\hline & $\begin{array}{l}\text { Embedded heat- } \\
\text { pipe }\end{array}$ & $\begin{array}{l}\text { Heat-pipe is embedded with } \\
\text { high thermal conductivity } \\
\text { material }\end{array}$ & $\begin{array}{l}\text { Heat-pipe and high thermal conductivity material can both } \\
\text { transfer heat isothermally. And embedded structure is more } \\
\text { stable. }\end{array}$ \\
\hline
\end{tabular}

\section{Heat-balance thermal protections with high thermal conductivity material}

Heat-pipe mainly uses fluid to transfer heat. Heat pipes transfer heat nearly isothermally by the evaporation and condensation of a working fluid, as illustrated in Fig. 1. The heat is absorbed within the heat pipe by evaporation of the working fluid. The evaporation results in a slight internal pressure differential that causes the vapor to flow from the evaporator region to the condenser region, where it condenses and gives up heat. The cycle is completed with the return flow of the liquid condensate to the evaporator region by the capillary action of a wick. When heat-pipe is used to cool hypersonic leading edge, it can be design as Fig. 2.

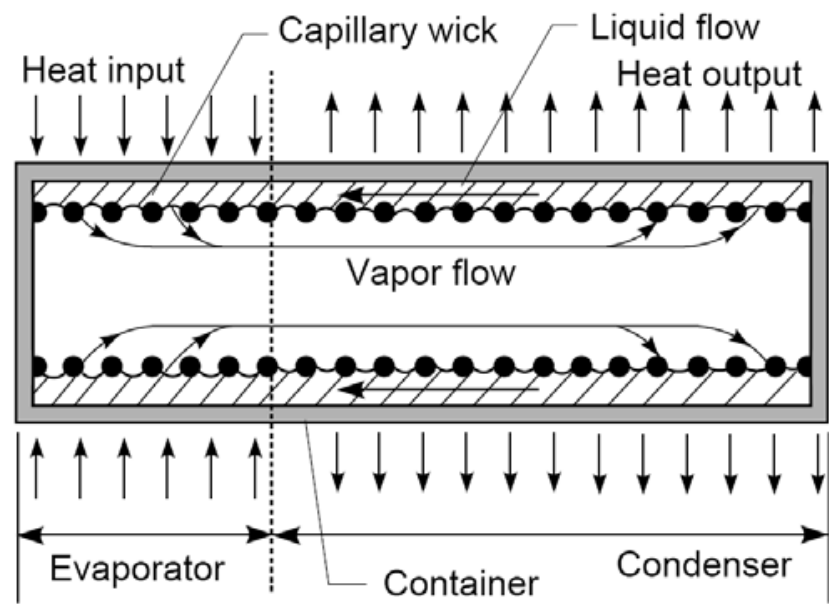

Figure 1. Schematic diagram of the operation of a heat pipe showing the heat-pipe container, working fluid, and wick.

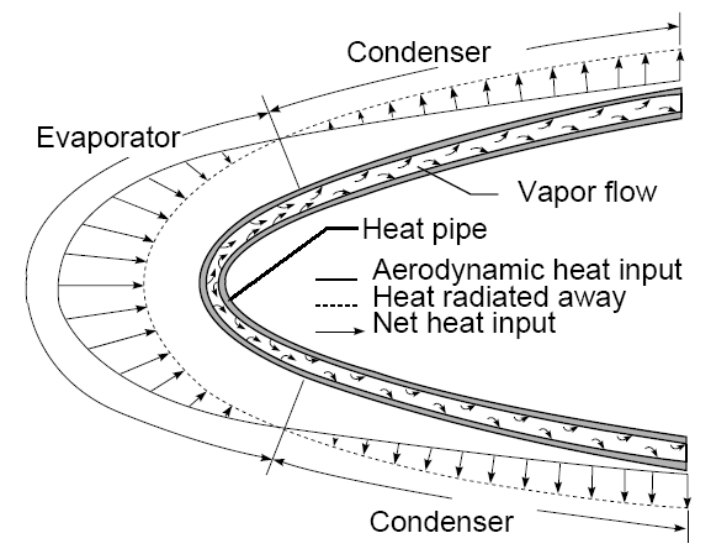

Figure 2. Schematic diagram of a heat-pipe-cooled leading edge showing regions of net heat input (evaporator) and net heat output (condenser)

Working fluid is an important factor in heat-pipe working effect. The choice of working fluid is related with working conditions and will affect heat transfer. There are appropriate working fluids at different temperatures for heat-pipe in Fig. 3 [1]. From Fig. 3, it is known that metals such as $\mathrm{K}, \mathrm{Na}$ and $\mathrm{Cs}$ could be used as working fluid when temperature is high. In the same temperature region, like $550 \mathrm{~K}-740 \mathrm{~K}$, Cs is a better choice for working fluid than $\mathrm{K}$. But $\mathrm{K}$ will be better when temperature is higher than $740 \mathrm{~K}[2]$.

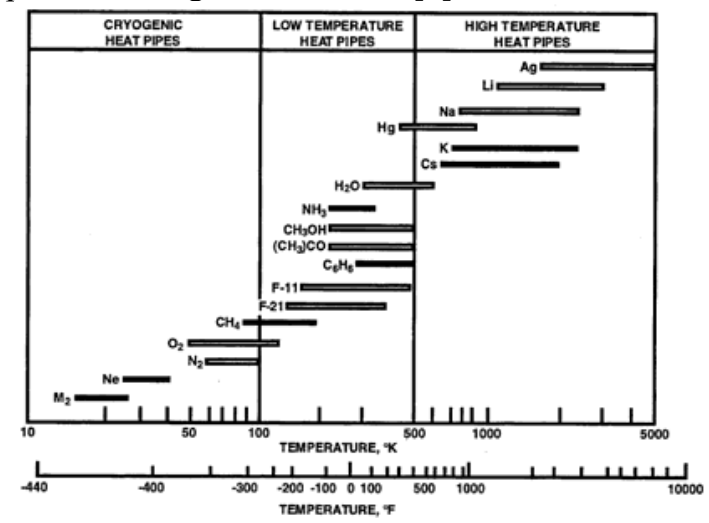

Figure 3. Appropriate working fluids at different temperatures for heat-pipe [1] 
Heat-pipe does not need special energy supply to work, and it has high thermal conductivity. The hard container can be used as support structure. These advantages enable heat-pipe to be widely used in heat control and heat-balance thermal protection. In early 1966, a first W-Li super high temperature heat-pipe was developed [3]. In last century 70's, heat-pipe was used for heat control on space vehicles [4-6]. Donovan [7] used heat-pipe as heat-balance thermal protection for missile fin. Buffone [8-9] used liquid metal ( $\mathrm{Na}$ and Li) heat-pipe to cool rocket nozzle wall.

The research on heat-pipe cooled leading edge for hypersonic vehicle began in last century 70's. NASA Langley Research Center (LaRC), through a contractual study, analytically verified the viability of heat pipes for cooling stagnation regions of hypersonic vehicles [10]. Niblock [11] proposed four space shuttle wing leading edge concepts, in one of which is a liquidmetal/superalloy heat-pipe-cooled concept. The heatpipe-cooled concept was determined to be a feasible and durable design concept, but was slightly heavier than the other candidate concepts. In 1973, Camarda [12] fabricated a half-scale shuttle-type heat-pipe-cooled leading edge to verify feasibility of the concept (see Fig. 4). This model was tested by a series of radiant heat and aerothermal tests at NASA LaRC from 1977 to 1978 to verify heat-pipe transient, startup, and steady-state performance [12-14]. In 1979, to optimize a heat-pipecooled wing leading edge for a single-stage-to-orbit vehicle, Peeples's [15] study indicated that the mass of a shuttle-type heat-pipe-cooled leading edge could be reduced by over $40 \%$ by use of a more efficient structural design. In 1986, Boman [16] designed and fabricated a sodium/superalloy heat-pipe- cooled leading edge component for an advanced shuttle-type vehicle. This advanced shuttle-type heat pipe was $1.83 \mathrm{~m}$ long and was tested by radiant heating and by induction heating [17-18].

In 1988, a Haynes 25/sodium leading-edge-shaped heat pipe with a "D-shaped" cross section was designed and tested by Clark [19]. The heat pipe had a length of $30 \mathrm{~cm}$, and a wall thickness of $0.076 \mathrm{~cm}$. Thermal performance, vibration sensitivity, and critical heat flux tests were conducted. Straight niobium/lithium heat pipes with a "D-shaped" cross section and a $0.06 \mathrm{~cm}$ thick wall have also been fabricated and tested by Wojcik[20-21]. These heat pipes had an oxidation resistance coating on the outer surface.

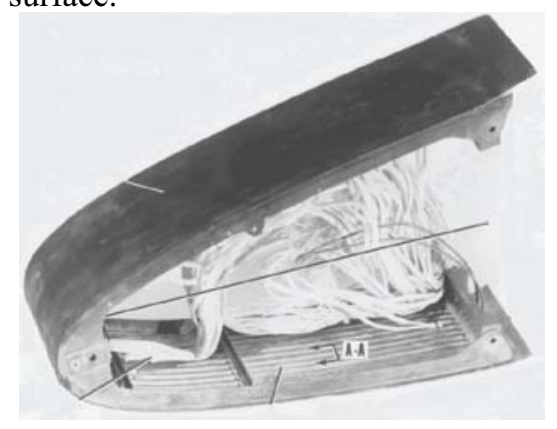

Figure 4. Heat-pipe cooled leading edge [12]

In 1992, Glass designed a heat-pipe-cooled leading edge which could reduce the leading-edge mass by over $50 \%$ compared to an actively cooled leading edge and could completely eliminate the need for active cooling, and has the potential to provide failsafe and redundant features [22]. It was a Mo-Re heat-pipe, used lithium as the working fluid and embedded in $\mathrm{C} / \mathrm{C}$ (see Fig. 5). From 1992 to 2006, Glass [22-29] did a lot of research on heat-pipe-cooled leading edge by theory analysis, numerical simulation and experiments. During their tests, the heat-pipe-cooled leading edge worked nearly isothermally.
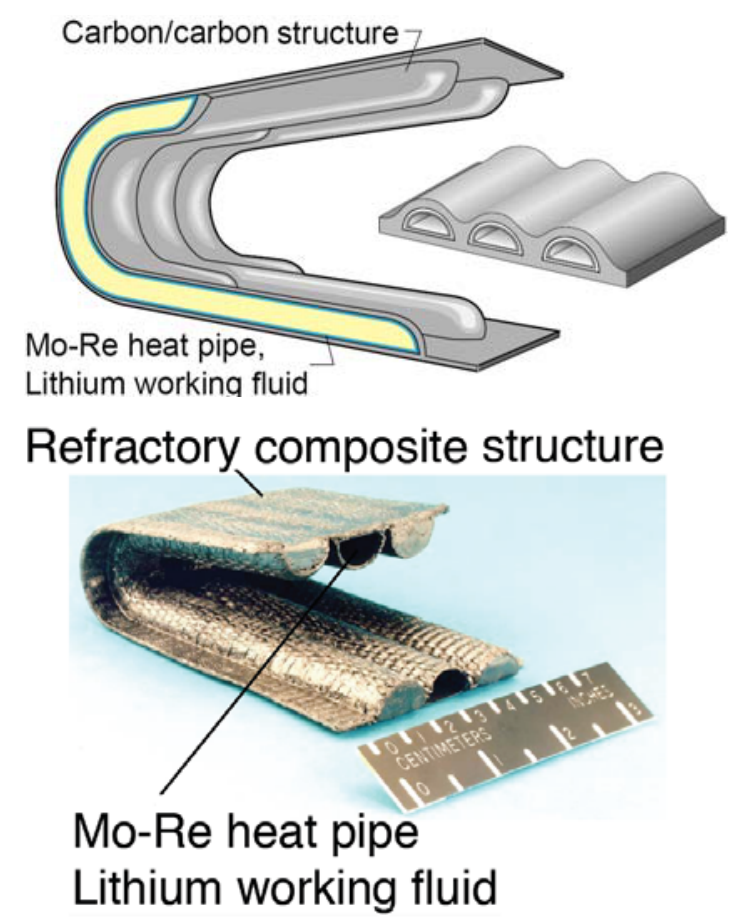

Figure 5. Shape and materials for heat-pipe-cooled leading edge In 2007, Steeves [30] examined the feasibility of metallic leading edge heat pipes, made of $\mathrm{Cb}-752$ and used $\mathrm{Na}$ as the working fluid, for hypersonic vehicles in Mach 7 flight. The heat pipes integrated within metallic leading edges provided very high effectively thermal conductivity which allowed heat to be transferred from the hot leading edge to large cool surfaces for radiation into space. Different materials were analyzed by Steeves [31]. Compared with Inconel 625 heat pipes used $\mathrm{Na}$ as working fluid, $\mathrm{Cb}-752$ heat pipes used $\mathrm{Li}$ as working fluid have better thermal protection effect.

Chen [32-34] conducted experiments on heat pipes, used alkali metals as working fluid (see Fig. 6), for thermal protection system for hypersonic vehicle within the atmosphere. Compared with composite material, the stagnation point temperature was reduced by $9.5 \%$ and temperature at the contact position of the sphere and cylinder was reduced by $10.4 \%$. And wall temperature at the position $130 \mathrm{~mm}$ away from the stagnation point was increased by $14.6 \%$. The results of experiments showed that heat pipes provided very high effectively thermal conductivity which allowed heat to be transferred from the hot stagnation region to cool surfaces. The feasibility of heat pipe used as heat-balance thermal protection for stagnation region of hypersonic vehicle was validated.

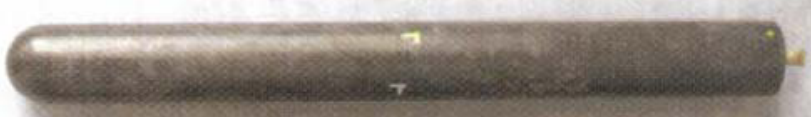

Figure 6. Photograph of high temperature heat pipe 
From 2009 to 2012, Liu [35-39] conducted numerical and experimental research on GH600 high temperature heat pipes, used $\mathrm{Na}$ as working fluid and embedded in $\mathrm{C} / \mathrm{C}$ coating, for vehicle leading edge structure. Discontinuous Galerkin finite element method was used for thermomechanical coupling calculation to simulate heat transfer of high temperature heat pipe cooled thermal protection structure. Two way heat pipes distribution was designed to reduce the stagnation point temperature efficiently and to increase structure reliability greatly. When reserving assembly gap was used, contact stress on the structure interface would decrease observably while thermal contact resistance would increase which raised the stagnation point temperature. Experiments on high temperature thermal contact resistance between 3D braided $\mathrm{C} / \mathrm{C}$ composite and high temperature alloy GH600 were conducted. The changing of thermal contact resistance with interface stress, interface roughness and interface temperature was obtained, which offered reference for design and safety evaluation on new high temperature heat pipe cooled thermal protection structure.

Due to the reported time, Table 2 is summarized.

Table 2. Heat-pipe-cooled leading edge for hypersonic vehicle

\begin{tabular}{|c|c|c|c|c|c|}
\hline Time & Author & $\begin{array}{l}\text { Working } \\
\text { fluid }\end{array}$ & Container & Coating & Ref. \\
\hline 1966 & Romano & $\mathrm{Li}$ & $\mathrm{W}$ & $\begin{array}{c}\text { No } \\
\text { coating }\end{array}$ & [3] \\
\hline 1978 & Camarda & $\mathrm{Na}$ & $\begin{array}{c}\text { Hastelloy- } \\
\text { X } \\
\end{array}$ & $\begin{array}{c}\text { No } \\
\text { coating }\end{array}$ & $\begin{array}{r}{[12-} \\
14] \\
\end{array}$ \\
\hline 1988 & Clark & $\mathrm{Na}$ & Haynes 25 & $\begin{array}{c}\text { Oxidation } \\
\text { resistance } \\
\text { coating }\end{array}$ & [19] \\
\hline 1990 & Boman & $\mathrm{Na}$ & $\begin{array}{c}\text { Hastelloy- } \\
\text { X } \\
\end{array}$ & $\begin{array}{c}\text { No } \\
\text { coating }\end{array}$ & $\begin{array}{l}16- \\
17] \\
\end{array}$ \\
\hline 1991 & Wojcik & $\mathrm{Li}$ & $\begin{array}{c}\text { Niobium } \\
\text { Alloy }\end{array}$ & $\begin{array}{c}\text { Oxidation } \\
\text { resistance } \\
\text { coating }\end{array}$ & $\begin{array}{l}{[20-} \\
21]\end{array}$ \\
\hline 1992 & Busse & $\mathrm{Li}$ & W-Re & $\begin{array}{c}\text { No } \\
\text { coating }\end{array}$ & [40] \\
\hline 1994 & Rovang & $\mathrm{Li}$ & 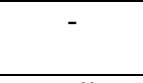 & $\begin{array}{c}\mathrm{C} / \mathrm{C} \\
\text { coating }\end{array}$ & [41] \\
\hline 1996 & Merrigan & $\mathrm{Na}$ & $\begin{array}{c}\text { Hastelloy- } \\
\text { X } \\
\end{array}$ & $\begin{array}{c}\text { No } \\
\text { coating }\end{array}$ & [18] \\
\hline 1992 & Glass & $\mathrm{Li}$ & Mo-Re & $\begin{array}{c}\mathrm{C} / \mathrm{C} \\
\text { coating }\end{array}$ & $\begin{array}{l}{[22-} \\
29] \\
\end{array}$ \\
\hline 2007 & Steeves & $\mathrm{Na}$ & $\mathrm{Cb}-752$ & $\begin{array}{c}\text { No } \\
\text { coating }\end{array}$ & [30] \\
\hline 2009 & Steeves & $\mathrm{Na}$ & $\begin{array}{c}\text { Inconel } \\
625 \\
\end{array}$ & $\begin{array}{c}\text { No } \\
\text { coating }\end{array}$ & [31] \\
\hline 2009 & Steeves & $\mathrm{Li}$ & $\mathrm{Cb}-752$ & $\begin{array}{c}\text { No } \\
\text { coating }\end{array}$ & [31] \\
\hline 2009 & Chen & $\begin{array}{l}\text { Alkali } \\
\text { metals }\end{array}$ & - & $\begin{array}{c}\text { No } \\
\text { coating }\end{array}$ & $\begin{array}{l}{[32-} \\
34]\end{array}$ \\
\hline 2010 & Liu & $\mathrm{Na}$ & GH600 & $\begin{array}{c}\mathrm{C} / \mathrm{C} \\
\text { coating }\end{array}$ & $\begin{array}{l}35- \\
39] \\
\end{array}$ \\
\hline 2011 & $\mathrm{Qu}$ & $\mathrm{Na} \& \mathrm{Li}$ & $\begin{array}{l}\text { Niobium } \\
\text { alloy }\end{array}$ & $\begin{array}{c}\text { No } \\
\text { coating }\end{array}$ & [42] \\
\hline
\end{tabular}

These research works by theory analysis, experiments and numerical simulation validated the feasibility and effect of heat-balance thermal protection by using heatpipes. With these works, heat-balance thermal protection could be known qualitatively and quantitatively.

\section{Working Condition of Heat-balance Thermal Protections}

During hypersonic flight, there is serious aerodynamic heating, especially on leading edge. The heat flux on leading nose whose radius is $20 \mathrm{~mm}$ can reach $2 \sim 3 \mathrm{MW} / \mathrm{m}^{2}$ and the wall temperature can reach $1400 \mathrm{~K}$ when the vehicle Mach number is 7 and flight altitude is $24 \mathrm{~km}$. And the heat flux on leading nose whose radius is $1 \sim 2 \mathrm{~mm}$ can reach $4 \sim 5 \mathrm{MW} / \mathrm{m}^{2}$ and the wall temperature can reach $1600 \sim 1900 \mathrm{~K}$ when the vehicle Mach number is 6 and flight altitude is $25 \mathrm{~km}$. When the vehicle Mach number is $10 \sim 20$ and flight altitude is about $100 \mathrm{~km}$ And the heat flux on leading nose whose radius is $10 \sim 30 \mathrm{~mm}$ can reach $10 \mathrm{MW} / \mathrm{m}^{2}$ and the wall temperature can reach $2000 \mathrm{~K}$.

When wall temperature is larger than critical temperature such as melting point, ultimate strength, and the aerodynamic structure has to be kept from burning out, heat-balance thermal protection could be a good choice for thermal protection system. However, wall temperature should be lower than container melting point to prevent working fluid from leaking. Working fluid should be chosen according to working conditions to make sure part of working fluid remains liquid to keep working cycle going on.

Heat-pipe-cooled leading edge is used as heat-balance thermal protection for hypersonic vehicle [29]. It started to work when wall temperature is $2255 \mathrm{~K}$ and the leading edge was nearly isothermal at $1870 \mathrm{~K}$. The heat pipes provided very high effectively thermal conductivity which allowed heat to be transferred from the hot leading edge to large cool surfaces for radiation into space.

\section{Conclusions}

Heat-balance thermal protection is non-ablating thermal protection, which can prevent the aerodynamic structure of hypersonic vehicle from burning down with the serious aerodynamic heating. Heat-balance thermal protection provides very high effectively thermal conductivity which allows heat to be transferred from the hot leading edge to large cool surfaces for radiation into space. It is validated by research with theory analysis, numerical simulations and experiments. In China, we are still at the primary stage. Learning abroad is a good way to make fewer mistakes while developing quickly. In order to develop heat-balance thermal protection, we could consider:

- Develop or choose new materials for container and working fluid;

- Develop or choose new materials for heat pipe coating;

- Design new structure for heat pipes;

- Design new heat-balance thermal protection.

Heat-balance thermal protection is a different thought changing from heat proof into heat control, which keep the whole vehicle as isothermal as possible. The research on heat-balance thermal protection will offer more efficient practical solutions to solve the seriously aerodynamic heating on hypersonic vehicle. 


\section{Acknowledgement}

This research is supported by Natural Science Foundation Project of Shaanxi Province (No. 2014JQ7275) and China Postdoctoral Science Foundation Grant (No. 2015M582911). The authors would like to express their appreciations for the above fund supports.

\section{References}

1. S. W. Chi: Heat Pipe Theory and Practice (Hemisphere Publishing Corporation, Washington, DC., 1976).

2. P. M. Dussinger, W. G. Anderson and E. T. Sunada: 3rd International Energy Conversion Engineering Conference, San Francisco, California, 2005.

3. A. Romano, A. Fleitman and C. Klamut: Proceedings of the Symposium on Alkali Metal Coolants, Vienna, 1966.

4. J. Roukis, J. Rogovin and B. Swerdling: AIAA 6th Thermophysics Conference, 1971, AIAA-71-0410.

5. T. R. Jr. Scollon: AIAA 6th Thermophysics Conference, 1971, AIAA-71-0412.

6. M. Tawil, J. Alario, R. Prager and R. Bullock: AIAA 6th Thermophysics Conference, 1971, AIAA-720272 .

7. B. D. Donovan, W. S. Chang and J. M. Gottschlich: AD 358663, 1998.

8. C. Bruno and C. Buffone: 23rd International Symposium on Space Technology and Science, Matsue, Japan, 2002.

9. C. Buffone, C. Bruno and K. Sefiane: 39th AIAA/ASME/SAE/ASEE Joint Propulsion Conference and Exhibit, 2003, AIAA-2003-4452.

10. C. C. Silverstein: NASA CR-1857, 1971.

11. G. A. Niblock, J. C. Reeder and F. Huneidi: Journal of Spacecraft and Rockets Vol. 11 (1974), p. 314.

12. C. J. Camarda: NASA TN D-8468, 1977.

13. C. J. Camarda: NASA TP-1320, 1978.

14. C.J. Camarda and R.V. Masek: Journal of Spacecraft and Rockets Vol. 18 (1981), pp. 71-78.

15. M. E. Peeples, J. C. Reeder and K. E. Sontag: NASA CR 159096, 1979.

16. B. L. Boman, E. C. Citrin, E. C. Garner and J. E. Stone: NASA CR 181922, 1990.

17. B. L. Boman and T. Elias: AIAA Paper 90-1759, 1990.

18. M. A. Merrigan, J. T. Sena and D. E. Glass: Proceedings of the ASME Heat Transfer Conference, Houston, TX, 1996.

19. L. T. Clark and G. S. Glenn: AIAA Paper 88-2679, 1988.

20. C. C. Wojcik: 8th Symposium on Space Nuclear Power Systems, Albuquerque, NM, 1991.

21. C. C. Wojcik: AIAA Paper 91-1400.

22. D. E. Glass and C. J. Camarda: Progress in Astronautics and Aeronautics, AIAA, Washington, DC, 1992.

23. D. E. Glass, C. J. Camarda, J. T. Sena and M. A. Merrigan: AIAA 97-3876, 1997.

24. D. E. Glass, M. A. Merrigan and J. T. Sena: NASA/CR-1998-207642, 1998.

25. D. E. Glass: NASA CR-1998-208962, 1998.
26. D. E. Glass, C. J. Camarda, M. A. Merrigan, J. T. Sena and R. S. Reid: AIAA-99-4866.

27. D. E. Glass, C. J. Camarda, M. A. Merrigan and J.T. Sena: Journal of Spacecraft and Rockets Vol. 36 (1999), p. 79-86.

28. D. E. Glass, N. R. Merski, and C. E. Glass: NASA/TM-2002, 2002.

29. D. E. Glass: NASA/CR-2006, 2006.

30. Steeves, C. A., He, M. Y., Valdevit, L. et al. Metallic Structural Heat Pipes as Sharp Leading Edges for Mach 7 Vehicles[C], Proceedings of IMECE 2007, November 11-15, 2007, Seattle, USA.

31. C. A. Steeves, M. Y. He, L. Valdevit et al.: Journal of Applied Mechanics Vol. 76 (2009), p. 031014-1-9.

32. L. Chen, D. Ou and D. Liu: Frontier Science Vol. 3 (2009), p. 41-45.

33. L. Chen and D. Ou: Journal of Experiments in Fluid Mechanics Vol. 24 (2010), p. 51-54.

34. D. Ou, L. Chen, H. Chen, J. Yu and S. Chen: Aerospace Materials Technology No. 2 (2014), p. 5457.

35. D. Liu, X. Zheng and Y. Liu: Computer Modeling in Engineering and Sciences, Vol. 39 (2009), p. 263299.

36. D. Liu, X. Zheng and Y. Liu: Tsinghua Science and Technology Vol. 50 (2010), p. 1094-1098.

37. D. Liu, X. Zheng and Y. Liu: Acta Materiae Compositae Sinica Vol. 27 (2010), p. 43-49.

38. D. Liu, X. Zheng and Q. Huang: Acta Aeronautica et Astronautica Sinica, Vol. 31 (2010), p. 2189-2194.

39. D. Liu and X. Shang: Acta Aeronautica et Astronautica Sinica, Vol. 33 (2012), p. 1834-1841.

40. C. A. Busse: Heat Pipe Science, Advances in Heat Pipe Science and Technology.(Int. Academic Publishers, 1992).

41. R. D. Rovang and A. J. Juhasz: AIAA-94-4065, 1994.

42. W. Qu and H. Wang: Journal of Chemical Engineering, Vol. 62 (2011), p. 77-81. 